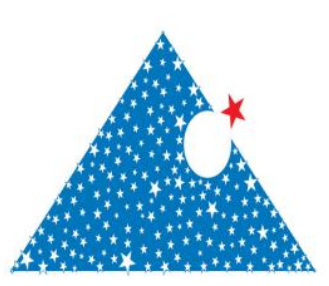

\title{
Sürtünme Karıştırma Kaynağında Farklı Karıştırma Uç Formlarının Oluşturduğu Kuvvetlerin Ve Birleşmeye Etkisinin Deneysel İncelenmesi
}

\author{
Hüdayim BAŞAK ${ }^{1}{ }^{*}$ Yunus KAYIR $^{2}$, Esra Hilal TÜRKYILMAZ ${ }^{1}$ \\ ${ }^{1}$ Gazi Üniversitesi Teknoloji Fakültesi, Endüstriyel Tasarım Mühendisliği Bölümü, 06500, Ankara/Türkiye \\ hbasak@gazi.edu.tr, hesracan85@gmail.com \\ ${ }^{1}$ Gazi Üniversitesi Teknoloji Fakültesi, İmalat Mühendisliği Bölümü, 06500, Ankara/Türkiye \\ hbasak@gazi.edu.tr
}

\begin{abstract}
Özet: İleri teknolojilerin uygulandığı gelişmiş endüstride mekanik parçaların kaynaklı birleştirilmelerinde faz dönüşümleri ve malzemede deformasyon genellikle istenmeyen bir durumdur. Bu olumsuzlukları gidermek, ancak malzemelerin mekanik ve metalurjik özelliklerini etkilemeyecek kadar düşük sıcaklıklarda yapılan birleştirme işlemleri ile mümkündür. Sürtünme karıştırma kaynağı (SKK), metal malzemelerin ergitilmeden katı faz ya da yarı katı halde birleştirilerek özellikleri korunur ve daha dayanıklı ve güvenli birleştirmeler elde edilebilir. Bu yöntemde kullanılan kaynak pimlerinin seçimi ve özellikleri de malzemenin birleştirme kalitesinde önemli ölçüde etkilidir. Bu çalışma ile SKK'da kullanılan pim tasarımları gerçekleştirilerek tasarlanan pimlerin imalatları gerçekleştirilmiştir. Altı farklı tipte karıştırıcı uç(pim) tasarlanmıştır. Kaynak esnasında oluşan kuvvetler bir dinamometre yardımıyla ölçülerek en iyi performans gösteren uç tespit edilmiştir. Aynı zamanda yapılan birleştirmelerden çekme deneyi için numuneler alınıp çekme testleri gerçekleştirilmiştir. Elde edilen tüm sonuçlardan faydalanılarak en uygun uç tasarımına karar verilmiştir.
\end{abstract}

\section{Experimental Investigation of the Different stirring pin forms caused force and its effects of joining on Friction Stir Welding}

\begin{abstract}
The application of the advanced technologies on developed industry, deformation and phase transformation on material in welded joints of mechanical parts is generally undesirable. To resolve these problems, it is possible to joining processes performed in the lower temperature will not affect mechanical and metallurgical properties. Metal materials properties is protected with joining solid or semi-solid phase state without melting and can be obtained more durable and Safety joining with Friction stir welding (FSW). The selection of the welding pin and properties used in this method has significantly effective on joining the quality of the material. In this study six different type stirrer pins, used FSW, have been designed and manufactured. The forces occurring during welding process was measured using a dynamometer and the best performing stirrer pin has been determined. At the same time, Specimens for tensile test have been taken from the joints made and tensile tests were carried out. Making use of all the results obtained, it was decided the most appropriate stirrer pin design.
\end{abstract}

Keywords: Friction Stir Welding, Stirrer pin profile, Force measurement, tensile test. 


\section{Giriş}

Gelişen teknoloji ile birlikte geleneksel yöntem olan ark kaynağı ile birleştirmelerin tüm malzemelerde kullanılamaması yeni yöntem arayışlarına sebep olmuştur. Bu sorunların ortadan kaldırılması için geliştirilen SKK, geleneksel ergitmeli kaynak yöntemleriyle zor olan, özellikle yaşlanma sertleşmesine tabi tutulmuş alüminyum alaşımlarının birleştirilmesinde başarıyla kullanılmıştır [1]. SKK ilk olarak 1991 yılında İngiltere(Cambridge)'de tanıtılmış, özellikle 1990'lı yıllarda gelişim göstermiş önemli bir kaynak yöntemidir [2- 4]. SKK halen yapılmakta olan çalışmalarla gelişim göstermektedir. Alüminyum ve alaşımlarının ergitmeli kaynak yöntemleriyle birleştirilmesinden doğan problemleri ortadan kaldırmak için birçok araştırmacı yeni yöntemler keşfetmiş ve SKK'nın farklı uygulanış yöntemleri ortaya çıkmıştır. Yapılan tüm çalışmalarda alüminyum ve alaşımlarında geleneksel yöntemlerde oluşan yüksek ısı girdisi ve bu malzemelerin ısı genleşmelerinin yüksek olmasından dolayı oluşan kaynak dikişlerindeki çatlakların oluşumunu SKK yöntemiyle yüksek oranda yok olduğu gözlemlenmiştir [5,6]. Bir katı hal kaynağı olan SKK, kaynaklı birleştirilmesi zor olan malzemelerin birleştirilme işlemlerinde kısa kaynak süresi, minimum yüzey hazırlama ve otomasyon kolaylığı gibi kendine ait avantajlardan dolayı tercih edilmektedir. $\mathrm{Bu}$ yöntem herhangi bir koruyucu gaz, ilave bir kaynak metali ya da kaynak ağzı açılmasına gerek kalmadığından dolayı alternatif bir yöntem olarak kullanılmaktadır [7].

Takım ucu profilinin şekli, yumuşamış malzemenin akışını ve kaynak özelliklerini etkiler [8,9]. Üçgen takım ucu profili silindirik takım profili ile karşılaştırıldığında malzeme akışı açısından daha iyi sonuç verdiği, çalışmalarda ortaya konulmuştur [10]. AA2024-T4 ve AA7075-T6 alüminyum alaşımları birleştirmelerinde 3 oluklu konik diş geometrisine sahip takım uç profilleri iyi kaynak birleştirmeleri sonucu vermişlerdir [11]. Pirinç malzemesinde Sürütünme karıştırma kaynağı ile birleştirilen takım uç profilinin mikroyapı ve mekanik özelliklere etkisinin incelendiği çalışmalar da mevcuttur [12]. Alüminyum alaşımlarının birleştirilmelerinde farklı uç profillerinin mikroyapı ve mekanik özelliklere etkisini inceleyen çalışmalar da yapılmıştır [13]. Aynı zamanda SKK'nın modellendiği çalışmalara da literatürde yer verilmiştir [14]. Sürtünme karıştırma kaynağı ile birleştirmelerde oluşan kuvvetlerin ölçümüne yönelik bazı çalışmalar da literatürde bulunmaktadır. Melendez ve arkadaşları, iş parçasında oluşan dikey kuvvetleri ölçmek için bir çalışma gerçekleştirmişlerdir [15]. Yang ve arkadaşları [16], yük hücresi kullanarak SKK esasında iş parçasında oluşan dikey kuvvetleri tespit eden bir algoritma önermişlerdir. Sürtünme karıştırma nokta kaynağında kaynaklama esnasında ortaya çıkan dikey kuvvetleri ölçen bazı çalışmalar da yapılmıştır $[17,18]$.

Bu çalışmada Al6066 kalite alüminyum alaşımı, farklı geometri ve farklı adımlara sahip karıştırıcı uçlar kullanılarak SKK yöntemiyle birleştirilmiştir. Birleştirme esnasında Fx, Fy, Fz kuvvetleri ve Mz moment ölçülmüştür. Deneyler sırasında uç devir sayısı ve ilerleme hızları sabit bir değer olarak belirlenmiştir. Kaynak işlemleri sonucunda numunelerden çekme deneyleri gerçekleştirilerek oluşan kuvvet ve momentlerle çekme deneyi sonuçları tartışılmıştır. $\mathrm{Bu}$ sayede oluşan kuvvetler, momentler ve çekme deneyi sonuçlarına göre en iyi uç profili tespit edilmeye çalışılmıştır.

\section{Materyal ve Metod}

Bu çalışmada AA6066 kalite alüminyum alaşımının farklı uç profillerine sahip karıştırıcı takımlar kullanılarak SKK ile birleştirilmesi esnasında oluşan kuvvetlerin belirlenmesi amaçlanmıştır. Elde edilen birleştirmelerden çekme numuneleri çıkartılarak çekme deneyleri gerçekleştirilmiştir. SKK esnasında oluşan kuvvetler ile çekme deneyi sonuçları beraber değerlendirilerek en iyi karıştırıcı uç’a karar verilmeye çalışılmıştır. Yapılan çalışma üç aşamada gerçekleştirilmiştir. Birinci aşamada pim tasarımı ile bağlama kalıbı tasarımı yapılmış ve pimlerin ve bağlama kalıbının imalatları gerçekleştirilmiştir. Karıştırıcı ucun profil tasarımı ve ölçüleri SKK'yı etkileyen önemli parametrelerden biridir. Karıştırıcı uç malzemesi olarak AISI4340 islah çeliği tercih edilmiştir ve 
malzeme 50-52 HRC sertliğinde isıl işleme tabi tutulmuş ve karıştırıcı uçlar SKK yönteminde kullanılmaya hazır hale getirilmiştir. Tasarımda pimin çapı Ø5 olarak alınmış ve üzerine aynı adım (p) değerinde yuvarlak, kare, trapez, testere, üçgen vida açılarak 5 adet vidalı uç (Şekil 1) ile ham kanallı pim tasarımı olmak üzere toplamda 6 adet pim tasarımı ve imalatı gerçekleştirilmiştir. Tasarlanan karıştırıcı uç'a ait temel ölçüler ve imalatı gerçekleştirilen karıştırıcı uç örneği Şekil 2'de verilmiştir. Vida çekilmiş pimlerde vida adımı (P) $1 \mathrm{~mm}$ pim boyu ise $5 \mathrm{~mm}$ olarak alınmıştır.

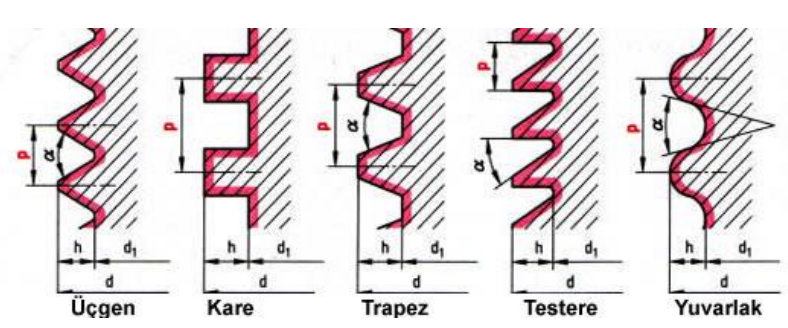

Şekil 1. SKK için kullanılan uçlara ait Vida profilleri (p: Vida adımı, $\alpha$ : Vida açısı, h: Vida derinliği, d1: Vida diş dibi çapı, d: Vida diş üstü çapı)

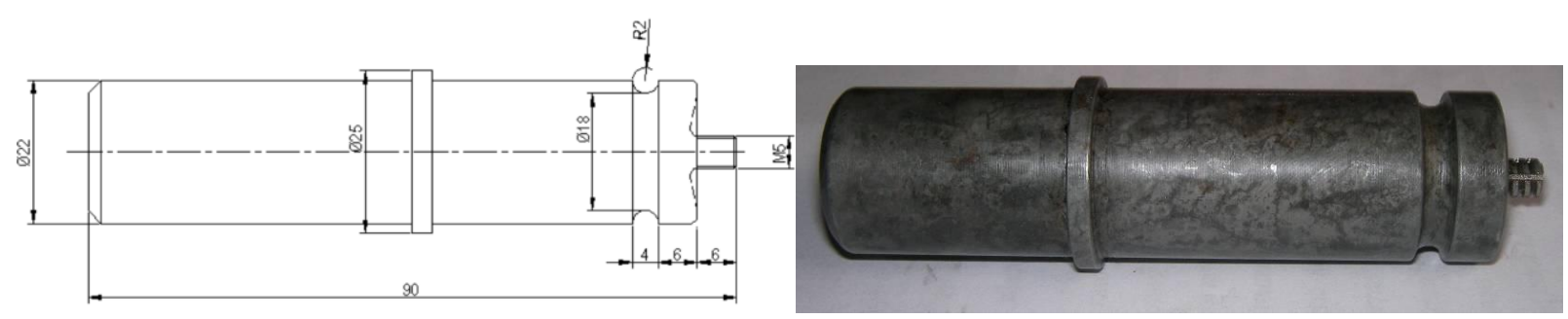

Şekil 2. Temel olarak tasarlanan karıştırıcı uç formu geometrik boyutları ve imal edilen karıştırıcı uç örneği

SKK ile birleştirilecek parçaların bağlanabilmesi için, dinamometre üzerine monte edilebilecek kabiliyette bir bağlama kalıbı tasarımı ve imalatı gerçekleştirilmiştir. İkinci aşamada, Üniversal Freze tezgâhında aynı parametreler (ilerleme f (mm/dev), Devir sayısı (dev/dak) ) kullanılarak parçalar SKK yöntemi ile birleştirilmiştir. Bu işlem esnasında 4 bileşenli (Fx, Fy, Fz ve Mz) ölçüm yapabilen bir dinamometre kullanılarak her pim tasarımı için kuvvet ve Moment ölçümleri yapılmıştır. Dinamometre, kuvvet ve moment ölçümleri için, üzerinde bulunan yükleri yönlerine göre $(\mathrm{X}, \mathrm{Y}, \mathrm{Z})$ algılayan ve sinyaller üreten piyasada hazır olarak temin edilebilecek KISTLER marka bir dinamometredir. Sistemde dinamometrenin oluşturduğu sinyalleri algılayan ve bilgisayar veri alma kartının algılamasını sağlayan bir Amplifier kullanılmıştır. Bilgisayara dinamometreden gelen ve amlifierle yükseltilen sinyallerin alınması için 16 kanaldan veri alabilecek kapasitede bir veri kartı kullanılmış ve bu karta deney setinde kullanılmak üzere bir yazılım yüklenmiştir. SKK gerçekleştirilirken oluşan kuvvet ve momentlerin ölçülmesinde kullanılan düzeneğin şematik resmi Şekil 3 de verilmiştir.

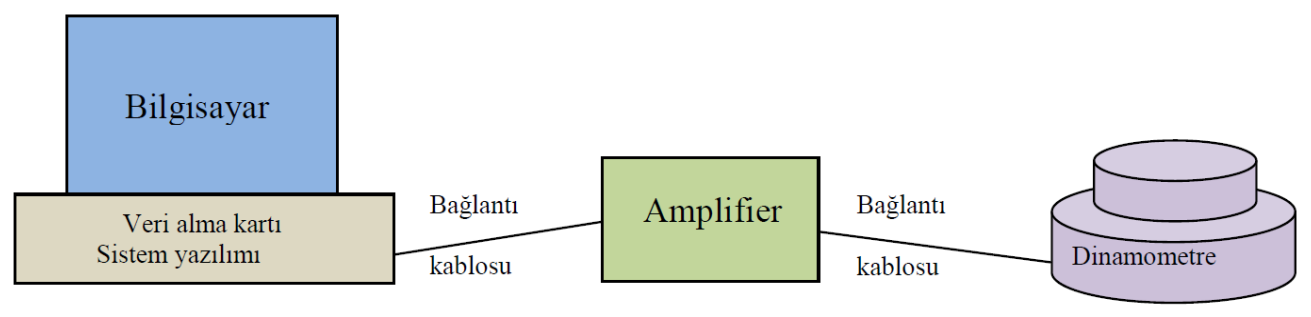

Şekil 3. Test düzeneği kurulumu 
Birleştirilen parçaların çekme mukavemetlerini analiz edebilmek için numuneler alınmış ve bu numunelerin çekme deneyleri Instron 3369 marka çekme cihazında 50kN çekme kuvveti ve $1 \mathrm{~mm} /$ dak ilerleme hızında gerçekleştirilmiştir.

\section{Deneysel Sonuçlar}

\subsection{Sürtünme Karıştırma Kaynağı}

Sürtünme kaynak yöntemi örnek alınarak SKK yöntemi geliştirilmiştir. Bu kaynak, yüksek devirde dönen omuzlu bir karıştırıcı ucun, alın alına sabitlenmiş iki levhaya daldırılarak hat boyunca belirli bir hızda ilerletilmesi ile gerçekleştirilir. Yöntemin özellikle kaynak yapılması çoğu zaman zor olan AA alaşımların birleştirilmesinde kullanıldığı görülmektedir. Bu kaynak yöntemi 1 mm' den az 35 mm' den daha kalın olan ve kaynaklanamaz olarak düşünülen alüminyum malzemelere uygulanmış ve çok iyi mekanik özellikler elde edildiğini görülmüştür [19]. SKK'nın yapım yöntemi Şekil 4'de gösterilmektedir.
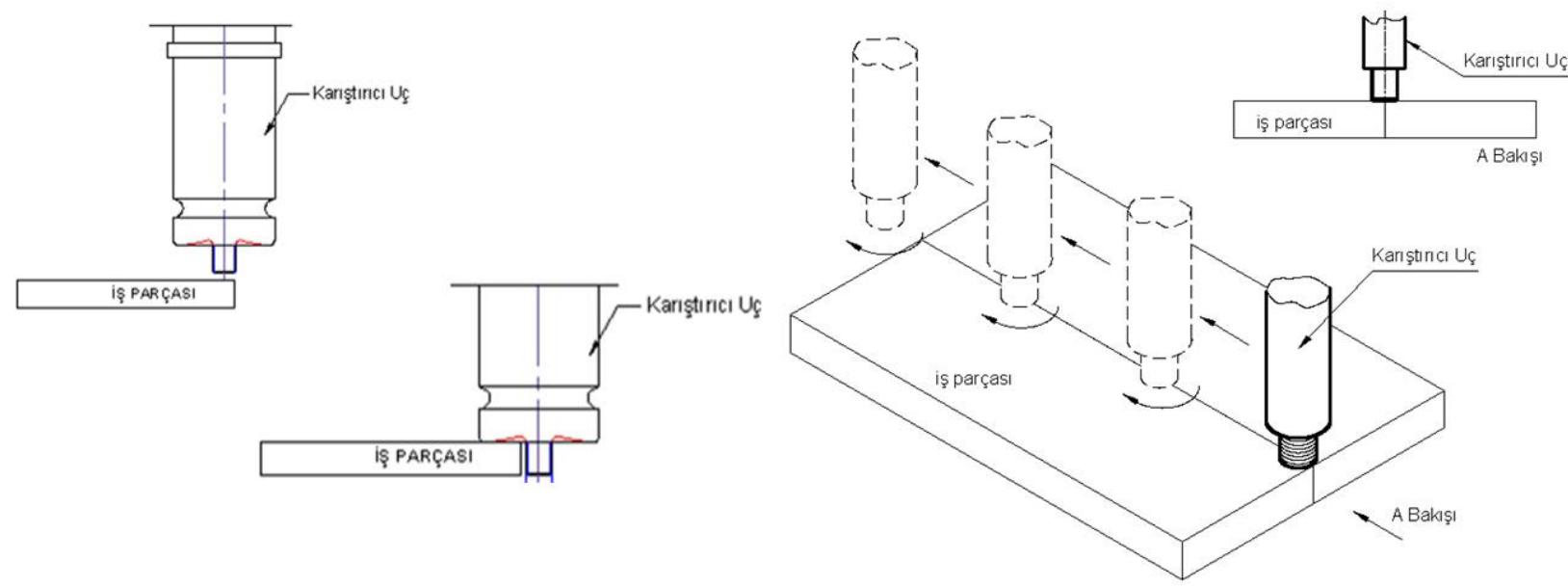

Şekil 4. Karıştırıcı ucun, alüminyum malzemeye kaynak öncesi hizalanması ve alaşımlı malzemeye karıştırıcı ucun yanaşması $[19,20]$.

Deneyler de kullanılan parametreler Tablo 1 de verilmiştir.

Tablo 1 Deney parametreleri

\begin{tabular}{|l|l|}
\hline Malzeme & AA6066 $80 \times 120 \mathrm{~mm}$ prizmatik parça \\
\hline Karıştırıcı uçlar & $\begin{array}{l}\text { Farklı uç profillerine sahip 6 adet } \\
(\mathrm{K} 1, \mathrm{~K} 2, \mathrm{~K} 3, \mathrm{~K} 4, \mathrm{~K} 5, \text { ve K6) }\end{array}$ \\
\hline İlerleme (f) & $31.5 \mathrm{~mm} / \mathrm{dk}$. \\
\hline Devir Sayısı (S) & $900 \mathrm{dev} / \mathrm{dak}$ \\
\hline SSK için kullanılan Tezgah & Taksan 40T1500 Üniversal dik freze tezgahı. \\
\hline
\end{tabular}

A16066 lama parçaları bağlama kalıbına alın alına gelecek şekilde bağlanarak işleme hazır hale getirilmiştir. Karıştırıcı uç Ø22'lik pens yardımı ile dikey freze tezgâhına bağlanmıştır. İşlem esnasında oluşan kuvvetleri ölçmek için tezgâh tablasına bir dinamometre düzeneği kurulmuştur. Bağlama kalıbı dinamometreye uygun şekilde civatalar yardımıyla bağlanmıştır. SKK için tespit edilen uygun devir sayısı $(900 \mathrm{~mm} /$ dak), ilerleme hızı $(31,5 \mathrm{~mm} /$ dak) kullanılarak iki parçanın birleştirilmesi gerçekleştirilmiştir. 


\subsection{Dinamometre Ölçümleri}

Yapılan ölçümlerde, Mz, moment değeri, SKK ucun kendi ekseni dönüşü sırasında durdurmaya çalışan yükü, Fz kuvveti, karıştıcı uçtan yukarı doğru çıkan malzeme hamurunun kesiciyi yukarıya doğru itme yükü, Fx ise karıştırıcnın ileriye doğru gitmesi sırasında kesicinin hareketini durdurmaya çalışan yükü temsil etmektedir. SKK deneyleri sırasında elde edilen grafiklerin yorumlanmasında, Fy yükü dikkate alınmamıştır. Çünkü SKK işlemi sırasında kullanılan karıştırıcıların dönme ve ilerleme olmak üzere iki hareketinden dolayı Mz, Fx yüklerinin etkili, karıştırılan AA6066 hamurunun kesiciyi yukarı doğru itmeye çalışmasından dolayı da Fz yükünün etkili olduğu varsayılmıştır. Dolayısı ile bu çalışmada dinamometre ölçülen üç kuvvet (Fx, Fy, ve $\mathrm{Fz})$ ve bir momentin $(\mathrm{Mz})$ değerlendirilmesinde Fy kuvveti değerlendirme dişında bırakılmıştır.

Altı farklı (K1, K2, K3, K4 ve K6) uç ile SKK deneylerin yapılması sırasında olası problemlerle (kırılma, kaynak işleminin yapılamaması, vb.) karşılaşılmamış olup kaynaklı birleştirmeler istenilen şekilde tamamlanmıştır. Deneyler sırasında dinamometre ile ölçülen kuvvetler ve moment değerleri Tablo 2'de, grafikler ise şekil 5'te toplu olarak gösterilmiştir.

Tablo 2'de sırası ile verilen Moment (Mz) değerleri incelendiğinde, en düşük moment değerinin (921 Ncm) yuvarlak (K2) ve kare (K4) vidalı uçlarla elde edildiği görülmektedir. Bu durumda, AA6066 malzemelerinin SKK yöntemi ile birleştirilmesinde kesici kırılmalarının en az yaşanacağ1 uç profillerinin yuvarlak ve kare vidalı uçların olacağı yorumlanabilir. Bununla birlikte ise en yüksek Mz değerinin $(6450 \mathrm{Ncm}) \mathrm{K} 1$ uçla (Ham kanallı) ortaya çıktığı görülmektedir. Dolayısı ile AA6066 malzemelerin SKK ile birleştirilmesinde K1 ucun uygun olmayacağı, işlemin zor gerçekleştirileceği, hatta uçların kırılabileceği sonucu çıkarılabilir.

Tablo 2'de verilen $\mathrm{Fz}$ değerleri incelendiğinde; karıștırıcı ucun vida tipi ve vida helis yönünün (burada tüm vidalı uçların vida helis yönü aynıdır) Fz kuvvetine etki ettiği görülmektedir. SKK işlemi sırasında sıcaklıkla birlikte hamurlaşan malzeme uçlar ile karıştırılırken aynı zamanda uçların vida helis yönü ile malzeme alttan yukarı doğru itildiği düşünülmektedir. Fakat Malzemenin yukarı doğru itilmesinde en düşük Fz $(121 \mathrm{~N})$ değerini yine normal üçgen vidalı uç (K3) vermiş olup diğerleri daha yüksektir. Bu durumda, SKK yöntemi ile AA 6066 parçalarının birleştirilmesinde üçgen vidalı uç ile ucu zorlamayacak olan en düşük Fz değerlerinin oluşacağ sonucuna varılabilir. Bununla birlikte kullanılan uçlar içinden ise en yükssek Fz değeri (5214 N) yuvarlak vida (K2) ile oluşmaktadır. Yuvarlak vidalı uç ile AA6066 hamuru parçaların alt yüzeyinden üs yüzeyine doğru büyük bir güç ile ilettiği söylenebilir.

Tablo 2'de verilen Fx değerlerine bakıldığında ise; en düşük değer (365 N) Üçgen vidalı uç (K3) ve en yüksek değer ise (1150 N) Testere vidalı uç (K6) ile elde edilmiştir. Bu durumda kesici AA6066 parçalarının SKK ile birleştirilmesi sırasında kaynak boyunca ucun ilerlemesinde üçgen vidalı ucun daha kolay (zorlanmadığı) ilerleyeceği, testere vidalı ucun ise daha zor (zorlandığı) ilerleyeceği sonucu ortaya çıkmaktadır.

Tablo 2. SKK deneylerinde kullanılan uçlar için belirlenen kuvvet ve moment değerleri

\begin{tabular}{|c|c|c|c|c|c|c|c|c|}
\hline Deneyler & Kesici No & $\begin{array}{c}\text { İlerleme } \\
\mathrm{f}(\mathrm{mm} / \mathrm{dev})\end{array}$ & $\begin{array}{c}\text { Devir } \\
\mathrm{S}(\mathrm{dev} / \mathrm{dak})\end{array}$ & $\begin{array}{c}\text { Kesici }(\mathrm{K}) \\
\text { Uc Tipi }\end{array}$ & $\begin{array}{c}\mathrm{Mz} \\
(\mathrm{Ncm})\end{array}$ & $\begin{array}{c}\mathrm{Fz} \\
(\mathrm{N})\end{array}$ & $\begin{array}{c}\mathrm{Fy} \\
(\mathrm{N})\end{array}$ & $\begin{array}{c}\mathrm{Fx} \\
(\mathrm{N})\end{array}$ \\
\hline 1 & $\mathrm{~K} 1$ & 31.5 & 900 & Ham kanallı & 6450 & 615 & 260 & 760 \\
\hline 2 & $\mathrm{~K} 2$ & 31.5 & 900 & Yuvarlak Vida & 921 & 5214 & 421 & 451 \\
\hline 3 & $\mathrm{~K} 3$ & 31.5 & 900 & Üçgen Vida & 1165 & 121 & 276 & 365 \\
\hline 4 & $\mathrm{~K} 4$ & 31.5 & 900 & Kare Vida & 921 & 2770 & 437 & 625 \\
\hline 5 & $\mathrm{~K} 6$ & 31.5 & 900 & Testere Vida & 1555 & 800 & 390 & 1150 \\
\hline 6 & $\mathrm{~K} 7$ & 31.5 & 900 & Trapez & 1875 & 1270 & 565 & 375 \\
\hline
\end{tabular}


Tablo verileri, Şekil 5'te verilen grafiklere bakıldığında SKK uçlarının işlem süresince karşılaştıkları yükler daha kolay görülmektedir.

Sonuç olarak SKK işlemi sırasında gene itibari en düşük yükleri üçgen vidalı uçlar ile elde edilebileceği yorumunu yapmak zor olamayacaktır. Diğer bir deyişle SKK işlemi için değişik profillere sahip uçlar içinde en uygun sonucu üçgen vidalı uç ile elde edileceği anlaşılmaktadır. Bu varsayım, SKK yapılan deney numunelerine uygulanan çekme sonuçları da (Şekil 6) göstermektedir.

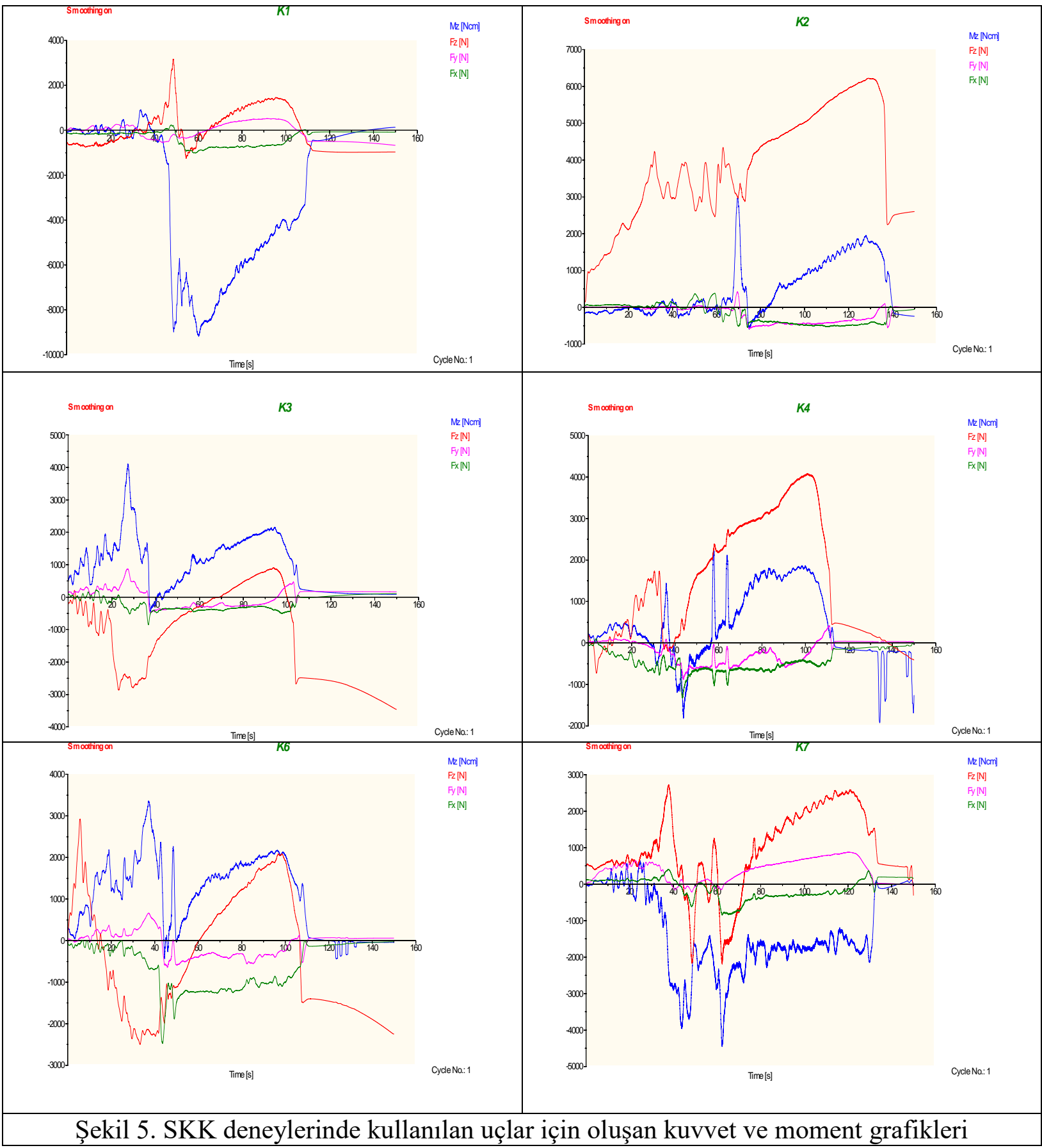

\section{3. Çekme testi}

SKK yöntemiyle bileştirilen kaynak numunelerinden 3 er Adet çekme numunesi çıkartılmıştır. Numuneler tel erozyon tezgahında istenilen ölçülerde kesilerek deney için hazır hale getirilmiştir. Çekme deney numuneleri TSE 138'e göre standart çekme numune ölçülerine göre hazırlanmıştır 
[21]. Çekme deneyi için hazırlanan numunelerin çekme deneyleri Instron 3369 marka çekme test cihazında gerçekleştirilmiştir. Deney sırasında çekme hızı $=5 \mathrm{~mm} / \mathrm{dak}$ ve Ön yük=10 $\mathrm{N}$ olarak belirlenmiştir. Şekil 6'da çekme deneyi için hazırlanan parçanın geometrik boyutları verilmiştir.

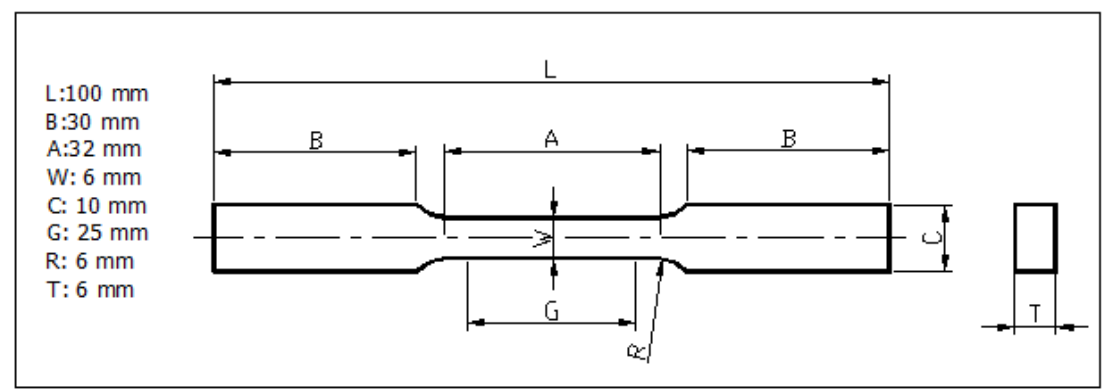

Şekil 6. Çekme deneyi için hazırlanan numunelerin geometrik boyutları

Çekme testine tabi tutulan çekme değerleri tablo 2'de verilmiştir.

Tablo 2 Çekme testi sonuçları

\begin{tabular}{|c|c|c|}
\hline $\begin{array}{c}\text { Deney } \\
\text { No }\end{array}$ & Parça / SKK kullanılan Uç & Çekme Değeri(N/Mm²) \\
\hline 0 & Ham parça & 347,68 \\
\hline 1 & Ham kanallı uç & 116 \\
\hline 2 & Yuvarlak vidalı karıştırıcı uç & 193,4 \\
\hline 3 & Üçgen vidalı karıştırıcı uç & 301,02 \\
\hline 4 & Kare vidalı karıştırıcı uç & 181,65 \\
\hline 5 & Testere vidalı karıştırıcı uç & 281,67 \\
\hline 6 & Trapez vidalı karıştırıcı uç & 232,55 \\
\hline
\end{tabular}

Vidalı karıştırıcı uçlar ile SKK'ya tabi tutulan numunelerin çekme mukavemeti, esas parça çekme mukavemetine yakın değerlerde çıkmıştır. Üçgen (metrik) vidalı karıştırıcı uç ile birleştirilen numunenin çekme mukavemeti en iyi değer $\left(301,02 \mathrm{~N} / \mathrm{mm}^{2}\right)$ olarak elde edilmiştir. En düşük çekme mukavemeti $\left(116 \mathrm{~N} / \mathrm{mm}^{2}\right)$ ise Vidasız kanallı profile sahip karıştırıcı uç ile elde edilmiştir.

Vida açılmayan karıştırıcı uç ile elde edilen çekme mukavemeti istenilen seviyenin çok altında çıkmıştır. Vidalı karıştırıcı uçlar ile yapılan numune parçalarda en düşük çekme mukavemeti kare vidalı karıştırıcı uç ile elde edilmiştir. SKK işleminin etkili olabilmesi için karıştırıcının yüzey alanının fazla olması gerektiği söylenebilir. Bu nedenle karıştırıcı uç geometrisine bağlı olarak yüzey alanı parametresinin doğrudan SKK işlemini etkilediği düşünülmektedir. Çünkü yüzey alanı artarken sürtünme işlemi daha etkili olacağından ortaya çıkan ısı miktarı da fazla olacaktır. Böylece iki parçanın birleştirilmesinde daha düzgün bir karışım sağlanacağı söylenebilir. Kullanılan vida geometrilerinin kaynak esnasında parçalarla temas ettikleri yüzey alanları düşünüldügünde elde edilen çekme mukavemeti sıralamasının da mantıklı olduğu kanaati oluşmuştur. 


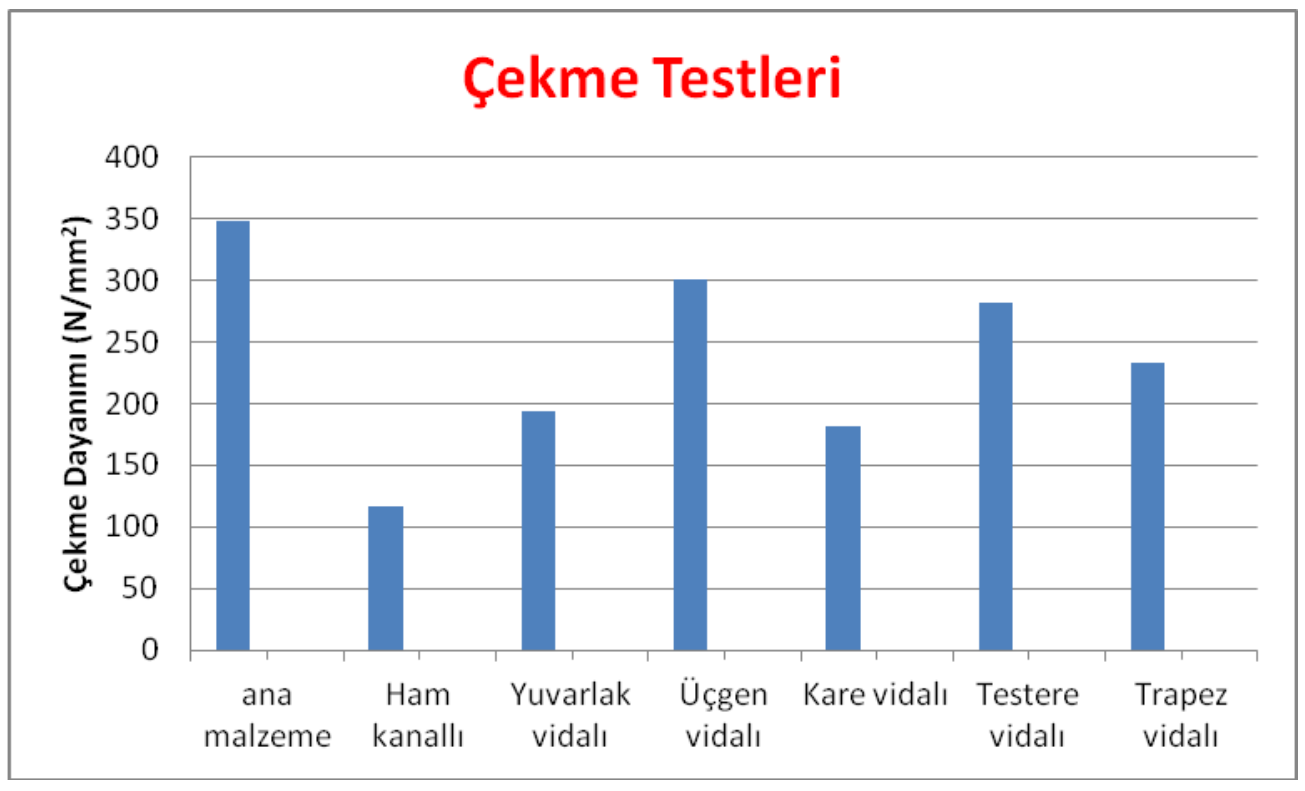

Şekil 7 Çekme testi sonuçları

\section{Sonuç Ve Öneriler}

$\mathrm{Bu}$ çalışmada SKK tekniği kullanılarak birleştirme işlemleri gerçekleştirilmiş ve uç profillerine bağlı olarak bir dinamometre vasıtasıyla oluşan kuvvetler ve moment değerleri belirlenmiştir. SKK tekniği ile birleştirilen numunelerden çekme deneyi için numuneler alınmış ve çekme deneyi testleri gerçekleştirilmiştir. En iyi performansı sağlayan karıştırıcı uç tespit edilmeye çalışılmıştır. Yapılan çalışma sonunda elde edilen bulgular aşağıda sıralanmıştır.

- Karıştırıcı uçlarda en iyi performans ve en mukavemetli birleştirme üçgen dişten elde edilmiştir. Karıştırıcı uç tasarımlarında bu tipin tercih edilmesi tavsiye edilir.

- Vidasız karıştırıcı uç ile yapılan kaynaklarda çekme kuvveti istenilen düzeyde olmamıştır.

- Vida çekilmiş karıştırıcı uçlar ile yapılan birleştirmelerde en kötü çekme mukavemeti sonucu kare dişli karıştırıcı uç ile birleştirilen numuneden elde edilmiştir.

- SKK yöntemi ile esas malzemeye yakın çekme mukavemeti elde edilebilir.

- Karıştırıcı uç tasarımlarında sürtünme yüzeyi fazla olan uçlar tercih edilirse birleşme daha homojen ve sağliklı olabilir.

- Karıştırıcı ucun vida sürtünme yüzeyinin büyüklüğü, kaynaklı birleşmenin çekme mukavemetini arttırdığı söylenebilir.

- SKK işlemi sırasında kullanılan karıştırıcıların dönme ve ilerleme olmak üzere iki hareketinden dolayı Mz, Fx yüklerinin etkili, karıştırılan AA6066 hamurunun kesiciyi yukarı doğru itmeye çalışmasından dolayı da Fz yükünün etkili olduğu anlaşılmıştır.

- SKK işlemi sırasında genel itibari en düşük yükleri üçgen vidalı uçlar ile elde edilebileceği anlaşılmaktadır.

- SKK işlemi için değişik profillere sahip uçlar içinde en uygun birleşimin üçgen vidalı uç ile elde edileceği görülmüştür. SKK yapılan deney numunelerine uygulanan çekme değerleri (Şekil 7) bunu kanıtlamaktadır.

\section{Kaynaklar}

[1] G. Çam: Sürtünme karıştırma kaynağı (SKK) :Al-alaşımları için geliştirilmiş yeni bir kaynak Teknolojisi, Mühendis ve Makine,46-541 (2005), pp. 30-39 
[2] H. Uzun, R. Özbekmez: Sürtünme Karıştırma ve Elektrik Ark Kaynak Teknikleri ile Birleştirilen CuZn30 Levhaların Mekanik Özelliklerinin Karşılaştırılması, SAÜ Fen Bilimleri Dergisi, 12-1, (2008), pp. 9-16.

[3] W.M. Thomas, E.D. Nicholas, J.C. Needham, M.G. Murch, P. Temple-Smith, C.J. Dawes: Friction Stir Butt Welding. International Patent Application No PCT/GB92/02203, GB Patent Application No.9125978.8, (1991)

[4] W. M. Thomas, E.D. Nicholas: Friction Stir Welding For The Transportation Industries, Metarials and Design, 18-4 (1998), pp. 269-273.

[5] A. Kurt, M. Boz, M. Özdemir: Sürtünme Karıştırma Kaynağında Kaynak Hızının Birleşebilirliğe Etkisi, Gazi Ün. Müh. Fak. Der., 19-2, (2004), pp. 191-197.

[6] A. Şık: Sürtünme Karıştırma Kaynağı İle Birleştirilen Alüminyum Levhaların Eğme Ve Yorulma Özelliklerinin İncelenmesi, SAÜ Fen Bilimleri Enstitüsü Dergisi, 9-2, (2005), pp. 1217.

[7] M. Çakır, A. Kurt, H. Ateş: Toz Metal Al Malzemelerin Sürütnme Karıştırma Kaynağında Devir Sayısının Kaynaklanabilirliğe Etkisi, Mühendis ve Makine, 49-580, (2008), pp. 3-8.

[8] M. K. Yadava, R. S. Mishra, Y. L. Chen, B. Carlson, G. J. Grant: Study of friction stir welding of thin aluminium sheets in lap joint configuration, Sci. Technol. Weld Join, 15-1, (2010), pp. 70-75.

[9] D. H. Choi, B. W. Ahn, C. Y. Lee, Y. M. Yeon, K. Song, S. B. Jung: Effect of pin shapes on joint characteristics of friction stir spot welded AA5J32 sheet, Mater. Trans., 51-5, (2010), pp. 1028-1032.

[10] S. Hirasawa, H. Badarinarayan, K. Okamoto, T. Tomimura, T. Kawanami: Analysis of effect of tool geometry on plastic flow during friction stir spot welding using particle method, J. Mater. Process. Technol., 210-11, (2010), pp. 1455-1463.

[11] M. Aissani, S. Gachi,F. Boubenider, Y. Benkedda: Design and optimization of friction stir welding tool, Materials and Manufacturing Processes, 25-11, (2010), pp. 1199-1205.

[12] A. Kumar, L. Suvarna Raju: Influence of Tool Pin Profiles on Friction Stir Welding of Copper, Materials and Manufacturing Processes, 27, (2012), pp. 1414-1418.

[13] M. Boz, A. Kurt: The influence of stirrer geometry on bonding and mechanical properties in friction stir welding process, Materials \& Design, 25-4, (2004), pp. 343-347.

[14] H. Okuyucu, A. Kurt, E. Arcaklioglu: Artificial neural network application to the friction stir welding of aluminum plates, Materials \& Design, 28-1, (2007), pp. 78-84.

[15] M. Melendez, W. Tang, C. Schmidt, J. C. McClure, A. C. Nunes, L. E. Murr: Tool Forces Developed during Friction Stir Welding, Nasa Technical Reports Server, (2003), Document ID: 20030071631.

[16] Y. Yang, P. Kalya, R. Landers, K. Krishnamurthy: Automatic Gap Detection in Friction Stir Butt Welding Operations, International Journal of Machine Tools \& Manufacture, 48, (2008), pp.1161-1169.

[17] S. Mandal, J. Rice: Experimental and Numerical Investigation of the Plunge Stage in Friction Stir Welding, Journal of Materials Processing Technology, 203, (2008), pp. 411-419.

[18] H. Badarinarayan, Y. Shi, X. Li, K. Okamoto: Effect of Tool Geometry on Hook Formation and Static Strength of Friction Stir Spot Welded Aluminium 5754-0 sheets, International Journal of Machine Tools \& Manufacture, 49, (2009), pp. 814-823.

[19] H. Basak, K. Kaptan: Analyzing The Effects Of Different Stirrer Pin Forms Over The Quality Of Joining In Friction Stir Welding Joints, Materiali in tehnologije / Materials and Technology, 49-5, (2015), pp. 693-701.

[20] H. Basak, S. Ozkan, A. Taskesen: Application of burnishing process on friction stir welding and investigation of the effect of burnishing process on the surface roughness, hardness and strength, Experimental Techniques, 35,1, (2011), pp. 8-16.

[21] Turkish Standard Instituation organization TSE 138 